\title{
Business Applications of THE EXPRESS TRUST
}

\section{ROBERT FLANNIGAN}

The trust is an important, often unappreciated, business instrument. Several of the various commercial applications of the trust are reviewed in the first part of this article. The author then focuses on some of the considerations involved in employing the trust as an alternative form of business organization. Special attention is given to the requirement of trustee autonomy and the office of "protector."
La fiducie est un instrument important, qui n'est souvent pas apprécié $\dot{a}$ sa juste valeur. Plusieurs des diverses applications commerciales de la fiducie sont passées en revue dans la première partie de l'article. L'auteur se penche ensuite sur certaines des considérations qui découlent de l'emploi de la fiducie en tant qu'autre mode d'organisation possible de l'entreprise. Une attention particulière est accordée à l'exigence d'autonomie du fiduciaire et à la fonction de "protecteur ".

\section{TABLE OF CONTENTS}

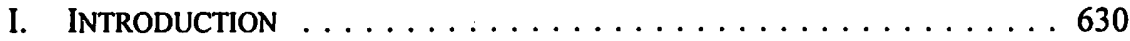

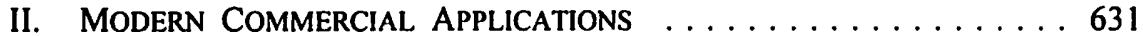

A. HOLDING PROPERTY/FACILITATING

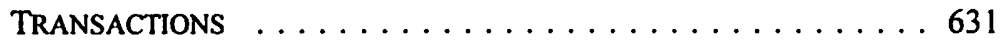

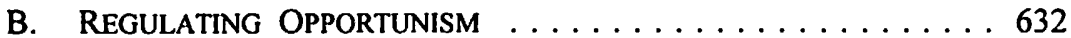

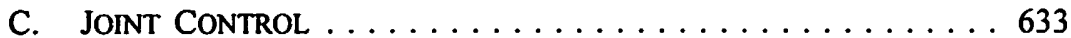

D. INVESTMENT VEHICLE $\ldots \ldots \ldots \ldots \ldots \ldots \ldots \ldots \ldots 633$

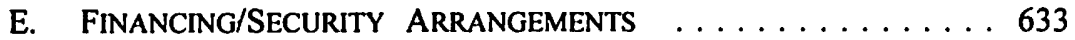

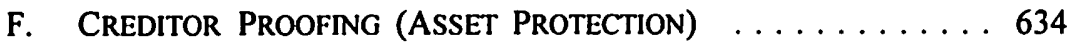

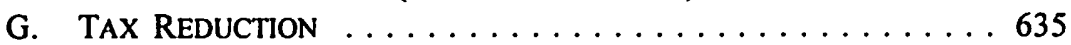

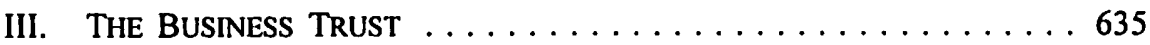

A. STRUCTURE AND FUNCTION $\ldots \ldots \ldots \ldots \ldots \ldots \ldots 6 . \ldots \ldots$

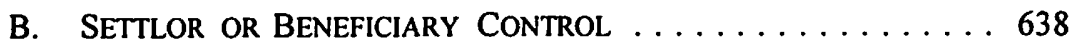

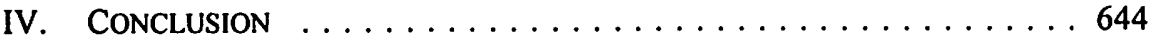

\section{INTRODUCTION}

The extent to which the trust is employed to serve commercial purposes is unknown and probably unknowable. There is no requirement for settlors or trustees to register this legal form or to disclose its existence in any general way. Anecdotal evidence, however, suggests that the trust flourishes in the commercial sphere. The various features of the trust are of considerable utility in numerous respects. These features include the separation of legal and equitable title, the absence of significant statutory regulation and the default fiduciary status of the trustees. These characteristics of the trust ensure that it will be employed, in one way or another, in many commercial transactions. Most of the various applications (e.g. financing, governance) will be perfectly proper. Others will involve impeachable attempts to avoid responsibility or taxation. 
It may be observed initially that no sharp line can be drawn between commercial and other applications of the trust. There is considerable conceptual difficulty in distinguishing between commercial and non-commercial activities.' Even private testamentary trusts will have a commercial quality to them if the property is a business or where the trustees contract for goods or services from third parties. Private trusts would also be "commercial" where, for example, they are utilized primarily as creditorproofing devices. As it stands, the commercial/non-commercial dichotomy is a vague, and largely unhelpful, analytical bifurcation of trust applications. ${ }^{2}$ It is not necessary to further consider this ostensible dichotomy, however, as the following discussion will be confined to those applications that are clearly of the commercial variety. We will first briefly review a number of significant commercial uses of the trust and then focus more closely on the trust as a form of business vehicle. The latter analysis includes a discussion of the efficacy of employing a "protector" to shield active settlors or beneficiaries from liability to third parties.

\section{MODERN COMMERCiAL APPLICATIONS}

\section{A. Holding Property/Facilitating Transactions}

One of the more common commercial uses of the trust is to hold property, either indefinitely or pending some event or prior transaction. The trust is employed here for reasons of secrecy or transactional convenience. For example, persons (developers) may wish to complete transactions (land assembly) without revealing their identities in order to avoid particular problems (holdout vendors) that might otherwise arise. All sorts of transactions in fact take place every day where either one or both of the parties, unbeknownst to the other party, is contracting as trustee for another person. It is also convenient for groups of persons to use trustees to hold their common property. This facilitates dealing with the property by requiring fewer persons to be involved in any particular transaction or to institute or defend litigation. This convenience has been recognized for many years. Prior to the advent of general incorporation legislation, many joint stock companies utilized trustees for this purpose. ${ }^{3}$ Trustees continue to be used today for the same reason by many unincorporated associations. Trusts are also employed to subordinate one creditor to another in order to obtain additional capital. It may also be convenient to use a trust, where markets for a security are thin or nonexistent, to support the initial issue of the security by arranging for its orderly retirement over a set period of time. A trust will also be effective to avoid difficulties created by the operation of the doctrine of privity of contract.

I

A similar, equally uncertain, dichotomy between profit-seeking and nonprofit objectives is employed in the attempt to distinguish partnerships from other associations. See R. Flannigan, "Contractual Responsibility in Nonprofit Associations" (1998) 18 O.J.L.S. (forthcoming).

2 The relevance of the bifurcation has never been demonstrated. There may be some sort of notion that the commercial applications of the trust "ought" to be treated differently. The basis for that "ought," however, remains elusive.

3 Had the trustees been given management of the assets, as well as title to them, a business trust would have been created. See R. Flannigan, "The Control Test of Principal Status Applied to Business Trusts" (1986) 8 E.T.Q. 37 at 40-42. 
It is often the case in some of these arrangements that the trustee is nothing more than a nominee or "bare" trustee. ${ }^{4}$ The trustee holds the legal title, but has no power to deal independently with the property. The trust deed will typically require the trustee to act only in accordance with the wishes of the settlor or beneficiaries. The effect of this is to alter the usual liability assignments relative to third parties. Where the trustees are truly autonomous actors, their status at law is that of principals, and they alone are liable in contract or tort to third parties. Where, however, they are subjected to external control, the external actor will be substituted for, or joined with, the trustee in carrying the liability burden. ${ }^{5}$ This liability assignment or adjustment occurs because the parties have actually constructed an agency relationship, with the agent/trustee merely holding legal title to the subject property. In this way the real character of the physical arrangement ultimately determines the rights of recourse available to third parties. If there are no third party effects, however, the trust form will apply because it was expressly selected by the parties to define the terms of their relationship. Thus, as between the trustees and beneficiaries, a "trustee" fiduciary obligation will operate unless expressly excluded by the trust deed.

\section{B. Regulating Opportunism}

It is worth separately emphasizing the role of the trust in serving as a convenient means of imposing a comprehensive fiduciary obligation on a person who is to hold property. The trust is associated with a notorious set of default fiduciary rules and principles that apply from the initial creation of the status. ${ }^{6}$ This is a considerable convenience to settlors, who need not incur the expense of drafting a comparable set of rules to control opportunism. It is also a convenience to the trustees who understand, or may easily ascertain, the content of the obligation imposed on them. The standard form content of the trust fiduciary obligation will usually be both more accessible, and more tested, than any specially drafted set of rules. The explicit adoption of this welldeveloped obligation will in most cases be preferable to relying on an ex post factbased determination of fiduciary responsibility. The settlor and trustee remain free, in every case, to negotiate specific modifications to the general default content of the obligation to accommodate their particular arrangement. Equity, Fiduciaries and Trusts (Toronto: Carswell, 1993) 213. Goodman is somewhat selective in the material he chooses to discuss. ed., Equity and Contemporary Legal Developments (Jerusalem: Hebrew University of Jerusalem, 1992) 275 at 276-77. Sec also R.L. Birnbaum \& J.F. Monahan, "The Nominee Trust in Massachusetts Real Estate Practice" (1976) 60 Mass. L.Q. 364 and P. Games \& J. Wright, "Protectors in the Isle of Man: Steele v. Paz Limited" (1995) 4 J. Inter. Trust \& Corp. Plan. 165. 


\section{JOINT CONTROL}

It may be important for a group of persons to act jointly and to be certain that there will be no defections from the joint purpose. One option is for the relevant control to be placed in the hands of trustees constrained to act solely in accordance with specific trust terms. An example is a voting trust where the voting shares of several shareholders are transferred to a trustee to vote those shares to attain defined objectives. ${ }^{7}$ The individual shareholders, who are now beneficiaries of the trust, have no power to defect except as might be allowed by the terms of the trust agreement. The most famous voting trust was that employed by Nelson Rockefeller to centralize in one body of trustees the control of numerous oil companies. His use of the voting trust ultimately sparked the development of anti-trust (now competition) legislation. ${ }^{8}$

\section{INVESTMENT VEHICLE}

Although they are examined later, one particular type of business trust may be mentioned here. It is usually efficient for numerous small investors to pool their capital. They will realize economies of scale in trades and have a greater ability to diversify their investments. The trust is one structure that is often used for this agglomeration purpose. Most mutual funds in Canada are in fact trusts. ${ }^{9}$ Where the trust units are offered to the public, they will be subject to general securities regulation, and, if traded on an exchange, to stock exchange rules. Pension funds are another type of investment trust. These funds have been plagued by serious conflicts because of the way they have been structured. Statutory regimes have been developed in many jurisdictions to govern their operation. ${ }^{10}$

\section{E. Financing/Security ARrangements}

Where debt is unitized or fragmented, it is usually convenient for the multiple lenders to be represented by a single trustee. The debtor will only be required to deal with the one person and one set of terms covering the loan and security. The arrangement also facilitates enforcement of the security by the lenders, as well as the transfer of lender interests. Corporate legislation in Canada applies a minimal level of regulation to such trusts. " Another arrangement involves the use of the trust to lend monies for a specific purpose. This amounts to a limited form of security because the

See D. Waters, "Voting Trust Agreements and the Zeidler Case" (1988-89) 9 E.T.J. 5 I (and addendum at 345). Note that, while an instrument may be called a voting trust, it may in fact only amount to a bare trust or a nominee relationship. See, for example, Field v. Bachynski (1976), 1 A.R. 491 (Alta. C.A.).

" See R. Flannigan, "Business Trusts - Past and Present" (1984) 6 E.T.Q. 375 at 380-81.

- See P. Botz, "Mutual Fund Trusts and Unit Trusts: Selected Tax and Legal Issues" (1994) 42 Can. Tax J. 1037. 
monies are recoverable ahead of other creditors if the purpose fails. ${ }^{12}$ It is necessary in connection with trusts generally to consider their efficacy relative to security registration systems that may be in place in the jurisdiction. ${ }^{13}$ The trust is often also the preferred legal form for asset securitization.

\section{F. Creditor Proofing (Asset Protection)}

Trusts may be employed in attempts to frustrate creditors. Historically, this has been one of the more common applications of the trust form. Property transferred to trustees for the benefit of a third party is no longer owned by the settlor and is therefore not available to satisfy the claims of creditors of the settlor. At the same time, the creditors of the trustee will not be entitled to take the trust property in satisfaction of the trustee's personal debts. The property is thus safely deposited in the hands of a sympathetic person (e.g. a spouse, relative, advisor) and is likely still available to be enjoyed by the settlor. This use of the trust has for some time been constrained by bankruptcy and fraudulent conveyance and preference legislation in order to protect existing creditors. However, it is still a technique to "protect" assets from the claims of future creditors (while usually continuing to have access to the assets) where, for example, a risky venture is about to be undertaken. Creditor proofing is also arranged through offshore trusts situated in jurisdictions that have an economic interest in hindering creditors of the settlor. A number of these jurisdictions have legislative provisions ${ }^{14}$ (and

Quitclose Investments Ltd. v. Rolls Razor Lid., [1970] A.C. 567 (H.L.). See M. Bridge, "The Quitclose Trust in a World of Secured Transactions" (1992) 12 O.J.L.S. 333.

Trust proceeds clauses will be treated as charges and governed by personal property security legislation.

For example, a short limitation period. See generally B.S. Engel, "Using Foreign Situs Trusts for Asset Protection" (1993) 20 Estate Planning 212 at 214 ("creditor will be confronted with a very tall, thick and wide brick wall"); E. Marty-Nelson, "Offshore Asset Protection Trusts: Having Your Cake and Eating It Too" (1994) 47 Rutgers L. Rev. 11 at 79 ("The authors of this legislation have gone to great lengths to make it virtually impossible for a creditor to reach the interests of a trust, even if the trust is self-settled"); N.C. Tobias, "The Uses and Abuses of Foreign Asset Protection Trusts," in Corporate Management Tax Conference 1993 (Toronto: Canadian Tax Foundation, 1993) c. 14; J.T. Lorenzetti, "The Offshore Trust: A Contemporary Asset Protection Scheme" (1997) 102 Commercial L.J. 138; P. Willoughby, "International Trusts Under Fire: The Expanding Scope of Litigation" (Dec./Jan. 1996/97) Offshore Investment 30, (Feb. 1997) Offshore Investment 23. In a brief note, J. Bernstein makes the following observations:

A trust can be invaluable in protecting assets from creditors, and offshore trusts are particularly popular for this purpose. The attribution rules and the foreign accrual property income rules generally eliminate any tax advantage of using an offshore trust, unless the trust has beneficiaries that are not Canadian residents.... Often there are no tax advantages to using an asset protection trust, and the only concerns are whether the trust will be effective against creditors and whether the transfer will invoke additional Canadian taxes.... Two of the more popular offshore jurisdictions for asset protection trusts are the Bahamas and the Cook Islands. In both of these jurisdictions, a creditor who does not take action against the trustees or trust property within two years of the assets' being settled on the trust are precluded from doing so under domestic law. These trusts are most effective for assets that can be moved outside Canada and settled on the trust. An unresolved question is whether a Canadian court would prevent a creditor from seizing an asset located in Canada but belonging to an offshore trust formed in such a jurisdiction ((1994) 2 Canadian Tax Highlights 69-70). 
judges), ${ }^{15}$ which discourage recourse to the trust assets even if an intention to defeat existing creditors can be established.

\section{G. TAX REDuction}

Tax avoidance is another ancient application of the trust form. In modern times the trust is used for conduit taxation, income splitting or as one component in complex or serial transactions designed primarily to reduce the tax burden. There are no general observations to be made here. The relevant provisions of the revenue legislation must be examined in each case to determine whether the trust will be effective in the circumstances.

\section{The Business Trust}

\section{A. STRUCTURE AND FUNCTION}

The trust form has been employed as a vehicle through which to operate an active business (including an investment business) for at least the last two centuries. ${ }^{16}$ The trust, however, has not been widely adopted as a business organization. ${ }^{17}$ The reason for this, apart from a lack of familiarity, is the very separation of benefit and control that makes the trust so useful for estate planning purposes. ${ }^{18}$ Many persons making a significant investment in a business are reluctant to assume a passive role and generally require rights of control that would be inconsistent with the autonomy the trustees must have. Nevertheless, there are investors who will accept a passive status and the trust can be an effective vehicle for them (e.g. mutual fund). The trust has other features that may be sufficiently attractive to particular parties such that their arrangements will be compressed or manipulated in order to be able to operate through this form. The two features that historically have driven the use of the business trust are its tax treatment and the lack of statutory regulation. ${ }^{19}$

The physical and legal structure of the business trust mirrors (and antedates) that of the statutory limited partnership. ${ }^{20}$ One or more principals administer property on behalf of others possessing a beneficial interest in the property. So long as the physical arrangement of the parties involves this separation of control and benefit, the passive

A striking exception to the norm of quiescence on the part of the judges of offshore jurisdictions is to be found in the judgment of Sir Duncan McMullin in the Cook Islands Court of Appeal decision in 515 South Orange Grove Owners Association v. Orange Grove Partmers (1995) (No. 208/94).

$16 \quad$ See Flannigan, supra note 8.

17 The business trust has recently been popular in Australia. Commentators have noted the difficulties these vehicles create for creditors. See generally H.A.J. Ford, "Trading Trusts and Creditor's Rights" (1981) 13 Melb. U.L.R. 1; D.G. Gardiner, "Trading Trusts and Straw Trustees" (1987) 3 Qld. Inst. Technol. L.J. 17; R. Hay, "Trading Trusts and Creditors' Rights" (1993) 67 Law Inst. J. 510.

14 See the other reasons mentioned in Flannigan, infra note 24 at 181-82.

$19 \quad$ See Flannigan, supra note 8.

20 See Flannigan, supra note 3 at 126-28. See also R. Flannigan, "The Control Test of Investor Liability in Limited Partnerships" (1983) 21 Alta. L. Rev. 303. 
investors will have limited liability. This is the case for both beneficiaries ${ }^{21}$ and limited partners. ${ }^{22}$ There are many reasons why investors would be prepared to accept a passive role. Their investment in the trust may be small relative to their other holdings, they may have little or no expertise in the business or they may be prohibited from exercising control of the business (e.g. foreign control restrictions). This requirement of passivity, it should be noted, is not absolute. There are a large number of rights which investors may possess. ${ }^{23}$ They may not, however, possess significant rights of control. As will appear shortly, the liability structure for the business trust has a contextual operation. If investors have significant control rights, the law will characterize them as principals (just as it does for limited partners) and fix them with open contractual and tortious liability.

The trust form will be selected over other vehicles on the basis of the aforementioned criteria. If investors are prepared to forego significant control, they may adopt this form. They will then have limited liability and the protection of a fiduciary obligation owed directly to them by the trustees. The undertaking will also avoid the extensive regulation associated with other organizational forms. The position of the investors will begin to approach the protected position of shareholders in corporations. Shareholders need not be passive (though they usually are), but their power to control is purchased at the cost of the substantial regulation applied to the corporate form. It is in fact the passivity of business trust investors, along with the fiduciary obligation and open liability of trustees, which justify the absence of extensive regulatory constraints on the business trust.

If the trust form is selected, the general rules of trust law apply. The creation, operation and termination of the structure will be determined by the relevant trust rules, except as the latter might validly be modified by the trust agreement. Breaches of trust will attract the usual equitable remedies. There are, however, a few matters that should perhaps be specifically mentioned. The first is that, for the typical arrangement, there should be no concern with the duration of the trust, although in practice it is common to limit the life of the trust to the perpetuity period. In most business trusts the interests of the beneficiaries are presently vested and freely alienable. It is also standard to include a provision allowing the trust to be terminated by a specified percentage of the beneficiaries. These features prevent the business trust offending public policy favouring the free circulation of property. Accordingly, as discussed at length elsewhere, where these physical characteristics are present, the trust will satisfy the rule against remoteness of vesting, the rule against restraints on alienation, and common law and statutory rules against extended accumulations. ${ }^{24}$

The second matter involves the use of a corporation to serve as the trustee of a business trust. Individual trustees are regarded as principals in relation to the trust undertaking and are fully liable for trust obligations. It is possible, however, to arrange 
limited liability for those individuals tentatively willing to serve as trustees by incorporating a corporation to act as the trustee, and appointing those persons directors of the corporation. This has been a common practice in Australia, where the trustee corporation is often nominally capitalized. ${ }^{25}$ In Canada, it appears that an ordinary corporation may act as a trustee at least incidentally in the course of its business without having to comply with trust company legislation. ${ }^{26}$ One question that arises, however, is whether beneficiaries may control the trust property by controlling the trustee corporation. In the limited partnership context, where the same issue arises, there are conflicting authorities. ${ }^{27}$ The risk is that limited partners who control a corporate general partner will lose their limited liability. ${ }^{28}$ That risk presumably also exists for business trust beneficiaries. Nevertheless, assuming it is tax efficient, it does appear that it would be permissible for trustees to incorporate themselves, at least where they are not also beneficiaries and where the business of the corporation could not be characterized as the business of a trust company. The other consequence of incorporation, obviously, is to shift the fiduciary obligation previously imposed on the individual trustees to the corporate trustee. This removes the regulating effect of a direct obligation on the individuals who remain in control of the corporate fiduciary, but some limited indirect protection for investors will still exist in the form of the fiduciary obligation the directors owe to the corporation itself.

The direct liability of beneficiaries is discussed in the next section. Before turning to that discussion, however, it is convenient to address the possibility that beneficiaries of a business trust might be made indirectly liable through the trustee's right of indemnification. While trustees are fully personally liable for obligations incurred in the course of operating the trust, they are entitled to be indemnified out of the trust fund and, if necessary, by adult beneficiaries who were settlors or who are absolutely entitled to the trust benefit. ${ }^{29}$ The latter indemnity will apply to the beneficiaries of most business trusts because they are usually the settlors and absolutely entitled. On the other hand, the right of indemnity is a default rule and may be excluded by the trust agreement. $^{30}$ If the agreement states that the trustees will have no right of indemnity from the beneficiaries personally, the exposure of the beneficiaries will be limited to their contribution to the trust fund. In some cases, however, a prospective trustee may be unwilling to give up the right to be indemnified. Whether or not the indemnity is contractually excluded will then be determined by the extent of the settlor's desire to employ that particular trustee.

2s See generally, supra note 17.

$26 \quad$ Re Thorne Riddell Inc. and Rolfe (1983), 149 D.L.R. (3d) 622 (B.C.C.A.).

27 Haughton Graphic Lid. v. Zivot (1986), 33 B.L.R. 125 (Ont. H.C.), aff d. (1988), 38 B.L.R. xxxiii (Ont. C.A.); leave to appeal to S.C.C. denied (1988), 38 B.L.R. xxxiii; Nordile Holdings Ltd. v. Breckenridge (1992), 66 B.C.L.R. (2d) 183 (C.A.). See R. Flannigan, "The Control of Investor Liability in Limited Partnerships" (1983) 21 Alta. L. Rev. 303 at 332-34.

Hardoon v. Belilios, [1901] A.C. 118 at 123 ("The plainest principles of justice require that the cestui que trust who gets all the benefit of the property should bear its burdens unless he can shew some good reason why his trustee should bear them himself").

See Flannigan, supra note 21 at 281-82. 


\section{B. SETTLOR OR BENEFICIARY CONTROL}

The default liability assignments applied to any particular structure are necessarily determined by the physical nature of that structure. The traditional conception of the trust structure is that the trustees hold and manage the property as principals, albeit for the benefit of others. Where the trustees are fully autonomous actors, they alone will bear the burden of direct responsibility to third parties for breaches of contractual or tortious duties. The trustees alone will have determined the risk that breaches will occur, either directly or through intermediaries, and they alone will be held liable in order to ensure that their risk-taking is not insulated or unregulated. This is the standard treatment of principals at law. At the same time, however, it must be understood that this treatment is conditioned on the trustees actually possessing the autonomy of principals.

The liability assignments change if the trustees are not in fact autonomous actors. ${ }^{31}$ The settlor of an inter-vivos trust may insist on retaining rights to control the trust property. Alternatively, the settlor may arrange for the beneficiaries to have significant powers of control. The retention of control is particularly likely to occur upon the creation of a business trust where the settlors (investors) settle property (their subscriptions) on trustees for themselves as beneficiaries. The investor settlors might grant to themselves in their beneficiary capacity rights to receive regular reports from the trustees, approve certain transactions, fill trustee vacancies, elect or remove the trustees or amend the terms of the trust. Some of these rights are unobjectionable; others constitute significant control powers. ${ }^{32}$ The difficulty with control powers is that they detract from the autonomy of the trustees and grant autonomy to the beneficiaries. The foundation for the assignment of liability to the trustees exclusively no longer exists. There are in fact new principals or co-principals now involved. ${ }^{33}$ When this occurs, the new principals must be made responsible for the same reason the trustees were originally made liable. If the law ignored this physical change by continuing to assign liability exclusively to the formal trustees, the risk-taking of the new principals (the beneficiaries) would be insulated or unregulated. If this risk-taking were not disciplined by requiring the beneficiaries to bear the adverse consequences of their actions, the level of risk associated with the trust undertaking would increase, and this would prejudice third parties. A large part of the law of obligations is designed to ensure that this does not occur in any context. The risk regulation policy underlies basic

The matter has been the subject of a debate in Canada. See the two articles by M.C. Cullity, "Liability of Beneficiaries - A Rejoinder" (1985-86) 7 E.T.Q. 35 and "Liability of Beneficiaries - A Further Rejoinder to Mr. Flannigan" (1986) 8 E.T.Q. 130, and the three articles by Flannigan, supra notes 3,5 and 21 (especially note 5).

32 See Flannigan, supra note 3 and 5.

33 Whether or not the beneficiaries are regarded as principals or co-principals depends on the autonomy of the trustees. If the trustees and beneficiaries each possess a degree of autonomy (e.g. in relation to distinct aspects of the trust undertaking), they are properly characterized as coprincipals. Where the trustees retain no real autonomy, or to the extent they are subordinate to the beneficiaries, they are properly characterized as agents, with the beneficiaries as the principals. Note, however, that this latter "agent" status does not necessarily relieve the agent/rustee of liability to third parties. 
contract and tort law, vicarious liability, ${ }^{34}$ corporate agency, ${ }^{35}$ the liability of members of unincorporated associations ${ }^{36}$ and the liability of limited partners. ${ }^{37}$ Liability for beneficiaries who control is simply one further manifestation of this public concern with insulated risk-taking. There are no considerations unique to the trust that suppress or overcome the general principle. ${ }^{38}$

In the case of the "bare" trust, it is universally conceded that the controlling actor (settlor or beneficiary) is personally responsible for contractual and tortious breaches. However, this concession does not exhaust the liability analysis, for it is premised on the assumption that a "bare" trustee is only a titleholder (agent or nominee) subject to an express requirement to comply in all respects with the instructions of the settlor or beneficiaries. While there are many such bare trustees, there are also many instances where the formal trustees retain some independent powers but are otherwise still required by the trust deed to defer either to the settlor or the beneficiaries on substantial matters. Accordingly, conceding the bare trustee circumstance does not fully satisfy or implement the risk regulation principle. It is not generally relevant, other than to establish their own co-principal status, that trustees possess one or more significant powers. $^{39}$ That tells us nothing about the status of others who potentially might be principals or co-principals. We could only confirm that other parties are not principals if it were clear that the trustees alone have complete de jure and de facto control of the trust undertaking. In that particular instance, the complete control of the trustees is simply a fact which forecloses or renders unnecessary further inquiry.

The proper inquiry to ascertain the liability status of settlors or beneficiaries must involve an examination of the rights they possess. It is those rights which will determine whether they are to be treated as principals for liability purposes. If those rights represent significant control, that contribution to the risk associated with the undertaking must be regulated by the assignment of liability. A control analysis, discussed elsewhere, must be undertaken to determine whether the settlors or beneficiaries possess a set of rights sufficient to characterize them as principals either together with or in substitution for the trustees. ${ }^{40}$ This analysis corresponds with traditional analyses throughout the common law which involve an examination of the relations of the parties to determine whether they are agents or partners to one another. ${ }^{41}$ It is also replicated in the analysis of the liabilities of members of nonprofit

See R. Flannigan, "Enterprise Control: The Servant-Independent Contractor Distinction" (1987) 37 U.T.L.J. 25.

See R. Flannigan, "Corporations Controlled by Shareholders: Principals, Agents or Servants?" (1986-87) 51 Sask. L. Rev. 23.

Flannigan, supra note 1 and R. Flannigan, "The Liability Structure of Nonprofit Associations: Tort and Fiduciary Liability Assignments" (1998) 77 Can. Bar Rev. (forthcoming).

See Flannigan, supra note 22.

The business trust form is already perceived to favour the interests of beneficiaries over those of creditors. See the materials supra note 17.

Cullity, supra note 31 , argues that no issue of beneficiary liability can arise if the trustee has any independent discretion. He provides no authority for that view. See Flannigan, supra note 5. Flannigan, supra note 3 at $110-26$.

Pooley v. Driver (1876), 5 Ch. D. 458; Martin v. Peyton 158 N.E. 77 (N.Y. 1927); Playfair Development Corp. Pty. Lid. v. Ryan, [1969] 2 N.S.W.R. 661 (S.C.). 
associations. ${ }^{42}$ It is, to emphasize once again, a conventional and conservative analysis of principal status, and, despite the strategic denial of some, it is plainly manifested in the authorities. ${ }^{43}$

The potential liability of settlors and beneficiaries to third parties has long been recognized in practice. That, however, has not discouraged investors from attempting to control their trustees. The desire to retain control is indeed a powerful one. Those who have collected significant assets are often uncomfortable handing over general management of those assets to bureaucrats in local or foreign trust companies or other trustees who may lack a comparable drive, expertise or sentiment. While they seek an end, they are reluctant to give up control, even if that risks defeating their original objective. The informal solution to their problem is to find a trustee (a relative or trust company officer) who will take instructions tacitly or covertly. But this is problematic, for friends and relatives can be unreliable, and professional trustees may decide to act, or be compelled to act, independently. The other solution is to employ a technique that is thought to allow for some formal measure of control over the trustees. Techniques that have recently been popular include taking the trust offshore, writing a letter of wishes, appointing a "protector" or, often, a combination of these techniques.

The offshore alternative involves finding a jurisdiction (usually a small island territory) that facilitates the primary objective (creditor-proofing, tax avoidance) while purporting to allow the settlor or beneficiary to retain effective control of the assets. ${ }^{44}$ The difficulty with this option is that the home jurisdiction may not recognize a trust structured in this way. The idea behind the letter of wishes option is that the trustee will formally be free to act autonomously, but will in fact act in accordance with the wishes of the settlor. ${ }^{45}$ It is likely thought that a court would give substantial weight to the express wishes of the settlor should the trustees subsequently presume to act in a different way. The obvious difficulty with this alternative is that the court may instead treat the letter as what it purports to be, a non-binding expression of a desire, and allow independent-minded trustees to act according to their own view of the trust terms and their fiduciary obligation to the beneficiaries. The third alternative, appointing a

See Flannigan, supra note 1.

See Cullity, supra note 31. As to the authorities, see Flannigan, supra notes 3 and 5.

Consider J. Mowbray, "Offshore Trusts: Illusion and Reality" (1994) 8 Trust Law Inter. 68; J. Mowbray \& J.A. Field, "When is Asset Protection an Asset Risk? Warnings and Alternatives" (1995) 4 J. Inter. Trust \& Corp. Plan. 3; R. Hay, "Canada: New Disclosure Requirements For Offshore Trusts" (1996) 5 J. Inter. Trust \& Corp. Plan. 105. See also the extract from the Ridley article, infra note 51 .

See Marty-Nelson, supra note 14 at 65 ; P. Matthews, "Letters of Wishes" (1995) 5 Offshore Tax Planning Review 181. See also W.D. Goodman, "Offshore Tax Planning: Beyond the Basics," in 1996 Conference Report: Report of Proceedings of the Forty-Eight Tax Conference, vol. 2 (Toronto: Canadian Tax Foundation, 1996) 57:1. According to Goodman (at 57:7), "[w]hile this letter is not intended to have any binding legal effect and while the settlor may make changes in it from time to time, conscientous [sic] trust officers of reputable trustee companies can be expected not to deviate from the guidelines set out in the letter of wishes, without first discussing the matter with the settlor." Query the significance of a settlor changing the provisions of the letter from time to time. Query also whether trust officers who are "expected not to deviate" from the letter of wishes are acting conscientiously. 
protector, ostensibly as an advisor or monitor, is probably the technique most likely to be employed in the case of a domestic business trust.

The appointment and conferral of powers on a protector is usually intended to avoid the appearance of any direct control link between the trustees and the settlors or beneficiaries. Control is instead exercised through the protector, who, through the application of a variety of levers, ${ }^{46}$ will be responsive to or guided by the views of the settlors or beneficiaries. It is thought that this will be an effective technique to protect the controlling actor, if not the protector or the trustees, from third party claims. ${ }^{47} \mathrm{An}$ effort is occasionally made to justify the use of protectors as a means of protecting the trust property against trustee opportunism. ${ }^{48}$ This is a weak argument, however, for two reasons. The first is that trustees are already constrained by the strict ethic of their fiduciary obligation. If that device does not inhibit self-serving trustees, it is unlikely that control powers possessed by a protector would be any more effective. ${ }^{49}$ As well, a question arises as to who is to monitor the opportunism of the protector. The employment of a protector simply increases the possible sources of breaches of care and loyalty. The second deficiency of the argument is that, in a sense, it proves too much. Obviously the best way to protect an investment is to control it. On this reasoning, total control of the trustees would be justified. ${ }^{50}$ This is plainly unacceptable from a liability perspective. The idea of protecting one's investment by controlling the trustees is simply incompatible with the conception that trustees are principals. Those who participate in controlling the affairs of the trust, whatever other status might concurrently be assigned to them, are the true principals for the purposes of third party claims.

Any lever will do. The possibilities include personal relationships, fee arrangements and dismissal powers. An alternative technique for investment decisions is to require the trustee to hire the "investment advisor" identified by (and likely the confidante of) the settlor. See Goodman, ibid. at 8.

47 The protector may be liable as a principal for third party claims and otherwise responsible as a de facto trustee. The trustees may be in breach of trust, if the trust terms do not clearly excuse their acts or omissions for failing to act in the best interests of all the beneficiaries.

It might be argued that it is not possible to characterize protectors as trustees where they do not hold the trust property themselves. See J. Mowbray, "Protectors" (1995) 5 Offshore Tax Planning Review 151 at 152. This is a technical and formalistic objection that likely would not prevent a court from supervising the management of the trust assets. Protectors are trustees to the extent they control the trust property. To satisfy the supposed technical concern, the protector may be understood to possess the legal title to manage the property. That is, the power of management (or part of it) is itself trust property, and was legally conveyed to the protector by terms of the trust deed. Alternatively, the technical objection may be dismissed on the standard ground that substance trumps form. It might also be concluded that the protector is a constructive trustee or a trustee de son tort.

See H. Rosen, "The Role of Protectors in Relation to Irrevocable Trusts" (1995) Private Client Business 36.

49 Monitoring powers, which are consistent with the policing rationale, but which are not control powers, would likely be more effective than direct control powers in regulating opportunism. Such powers might include rights to receive regular reports and financial statements, call meetings, inspect minutes or appoint auditors.

so See the discussion of Mollwo, March \& Co. v. Court of Wards (1872), L.R. 4P.C. 419 in Flannigan, supra note 3 at $89-94$, with respect to the argument that increasing control is justified by the coincident increase in investment protection. 
It seems clear enough that the primary motive for utilizing a protector is to exercise a measure of control over the direction of the trust assets. The practical literature appears to concede this. ${ }^{51}$ In the offshore context, where the use of protectors is currently popular, the protector may perform a variety of functions. ${ }^{52}$ The retention of control, however, is apparently the most common objective sought to be attained. To this end, the protector will often be given the power to remove trustees. A right of this significance, calculated to give the protector full power over the trustees, will almost certainly render the protector liable as a co-principal with respect to third party claims. ${ }^{53}$ The only issue will be whether the protector is in fact acting as the agent of the settlor or beneficiaries. It is well understood in practice that the right to remove the trustees is a powerful control device. ${ }^{54}$ Presumably settlors hope the control issue will

See Lorenzetti, supra note 14 at 149 ("One such device that secures the settlor's control over the trust is the establishment of a trust protector"); Mowbray, supra note 44 at 69 ("very often trustees lead prospective settlors to believe that their wishes will be obeyed and that they will not notice any difference in the way they are able to run their businesses after they are put into settlement"); A. Penney, "Rights and Powers of Trust Protectors: Rahman Revisited" (1995) 4 J. Inter. Trust \& Corp. Plan. 31 ("The use of trust protectors is one of the most obvious and commonly used means of the settlor to exercise continued influence over trust assets"); D. Harnett \& W. Norris, "The Protector's Position - Suggesting Some Basic Principles" (1995) Private Client Business 109 at 110 ("The Protector will act as a check on the trustees and ensure that the trust is administered in accordance with the settlor's wishes"); D.W.M. Waters, "The Protector: New Wine in Old Bottles?" in A.J. Oakley, ed., Trends in Contemporary Trust Law (Oxford: Clarendon Press, 1996) at 63.

Some of the risks to the trustee of allowing the settlor to control are noted by T. Ridley, "Special Trust Structures: A Helping Hand to the Professional Trustee" (1996) $5 \mathrm{~J}$. Inter. Trust \& Corp. Plan. 44. Ridley introduces his analysis with a typical client request to retain control:

In many circumstances clients of major financial institutions wish to use their offshore trust services for normal estate, tax and asset protection planning purposes, yet wish to minimize the involvement of the professional trustee, particularly while the client is alive.... Typically the client will be a successful and active entrepreneur who is very much a "hands-on" manager of his businesses and who has concerns about the stability of the jurisdiction where he lives and a desire to minimize his tax burden, to provide for an orderly continuation of his business after his death and to provide for future generations.... The client will, therefore, approach the professional trustee to ascertain if it will act as trustee of an offshore trust, say in the Cayman Islands, to be created by the client.... Most importantly the client will wish to transfer ownership of the privately-held family business to the trust. Often limited or no liquid assets will be transferred. Further, the client will not wish the trustee to dispose of or diversify the family business - certainly not without the client's approval, while he is alive. The client will also expect to be able to continue to run the family business as before (or to change its operations entirely) and the trustee not to interfere and second-guess or override management or board decisions. Goodman, supra note 45 at I1; A. Duckworth, "Protectors - Fish or Fowl?" (1995) 4 J. Inter. Trust \& Corp. Plan. 131.

If not merely the agent of the settlor, the protector will be liable as a principal on the standard control analysis. In essence, the protector becomes a trustee (or a principal, in the same way and for the same reason that a trustee is a principal).

See Flannigan, supra note 21 at 299-303 and supra note 3 at 112-14 and Marty-Nelson, supra note 14 at 65 . See also Goodman, supra note 45 at 10 , who recognizes that the removal power will alone be sufficient to effectively control trustees ("As a matter of prudence, it seems sufficient protection simply to restrict the protector's powers to the right to be given advance notice of any distribution proposed to be made by the trustee company and the right to require its resignation and replacement by another non-resident trustee company. In addition, it may be desirable for the 
be muddied somewhat by placing the right with a protector, rather than with themselves or the beneficiaries. All that this does, however, is force an expansion of the analysis. It becomes necessary to also investigate the nature of the relationship between the protector and the settlors or beneficiaries. If a control relationship is there found to exist, the controlling actors (the settlors or beneficiaries) may be held liable to third parties on the same basic analysis.

The use of a protector to maintain control over trustees has been found to constitute a "sham" in one recent case. 55 The sham notion, however, is a narrow and uncertain concept, and hardly begins to accommodate the risk regulation liability analysis. ${ }^{56}$ More straightforward, and entirely conventional, is the assessment of whether or not the protector is acting for or with the settlors or beneficiaries. If that is the case, the controlling parties may be found to be principals. This apparently is not well appreciated in the offshore trust industry, where there seems to be a degree of complacency, or even confidence, with respect to the wide powers that are often given to protectors. ${ }^{57}$ There is some sense in the literature that only extreme circumstances raise any appreciable risk. ${ }^{58}$ On the other hand, others have recently warned that the protector may not be the effective control device some might have thought. ${ }^{59}$ To date there has been little judicial analysis of the position of "protector." What exists, moreover, has come from the courts of offshore jurisdictions. When domestic courts investigate this issue, it may be expected that they will be less solicitous of the attempt to put forward puppet trustees.

The use of protectors (or of direct beneficiary control powers) in the business trust context will likely be defended on the basis that they provide investors with a degree of investment protection. However, as we have seen, this is a difficult argument to make. ${ }^{60}$ The resolution of any third party liability issue must depend on the analysis of the control rights the trustees, settlors, beneficiaries, or protectors possess. Those persons who have significant de jure or de facto rights to control the trustees or trust property must be held responsible for third party claims because they determined the

protector to have power to agree as to the remuneration of the trustee company").

Von Knierem v. Bermuda Trust Company Limited (July 13, 1994 unreported decision of Meerabux, $J$. in the Supreme Court of Bermuda). See Penney, supra note 51 and the case comment at (1994) 3 J. Inter. Trust \& Corp. Plan. 177.

Consider D. Hayton, "When is a Trust Not a Trust?" (1992) 1 J. Inter. Plan. 3; D. Brownbill, "When is a Sham Not a Sham?" (1993) 2 J. Inter. Trust \& Corp. Plan. 13.

See Rosen, supra note 48; Penney, supra note 51; Harnett \& Norris, supra note 51; Duckworth, supra note 52; J. Mowbray, "Protectors" (1995) 5 Offshore Tax Planning Review 151.

See Mowbray, supra note 44.

See Willoughby, supra note 14; Duckworth; supra note 52 (Duckworth criticizes the use of "dummy protectors" but would appear to find acceptable a wide range of protector powers and would allow beneficiaries to exercise control in a "protector" role). Note that the Canadian government has proposed reporting requirements for foreign trusts which require disclosure of the protector arrangements (and letters of wishes) along with the trust instrument. See Goodman, supra note 45; Hay, supra note 44; A. Baker, "New Foreign Reporting Requirements: Individuals and Trusts," in 1996 Conference Report: Report of Proceedings of the Forty-Eighth Tax Conference, vol. 2 (Toronto: Canadian Tax Foundation, 1996) 41:1.

See text supra notes 48-50. 
risk associated with the trust undertaking that generated those claims. This is nothing more than the conventional, even pedestrian, consequence of the projection of one's risk-taking.

\section{Conclusion}

Legal recognition of the trust form involved judicial acceptance of the idea that a person could take on the status and obligations of a principal in relation to particular property even though the benefit from the property was taken by others. It is in this idea that much of the commercial utility of the trust form is to be found. The difficulty that arises from time to time is that the parties will attempt to adopt the legal form of the trust without arranging for the trustee autonomy on which that form is premised. This is a particularly troublesome concern for the beneficiaries of a business trust because it will risk the loss of their limited liability.

The assignment of liability for third party claims varies with the nature of the physical arrangements parties make for themselves. If investors directly control their investment, they are subject to the liability structure that regulates the actions of principals. If they employ agents to manage their investment, while generally controlling those agents, they remain subject to the principal liability structure. Where, however, they choose merely to retain the benefit of the investment, the liability assignments are adjusted. The investors no longer control and there is no risk regulation basis for holding them liable as principals. The person or persons to whom control was transferred (e.g. trustees, general partners in a limited partnership or committee members in a nonprofit association) will alone be subject to the liability structure which governs principals. Each of these contextual liability assignments is determined by the control arrangements the parties have made. The basic proposition is that responsibility is placed with those who control. It applies equally to instances where different persons share or participate in control as joint or co-principals. This means that it is not enough to formally appoint trustees and to grant them a limited measure of independence or autonomy. This will not shield the investors from third party claims if they possess significant control powers, either directly, or indirectly through a protector whom they control. The limited liability of the investors is contingent on their passivity. Their investment protection is the fiduciary obligation owed to them by the trustees, as is the case for the beneficiaries of other trusts. If they are not passive, they must share the burden of the adverse consequences of the projection of their risk-taking. There is ample authority for this conclusion in the law of trusts and in the law generally. Accordingly, where liability exposure is an important consideration, the requirement of trustee autonomy represents a significant constraint on the commercial use of the trust. 